\section{Licensed to kill: the United Kingdom's arms export licensing process}

Anna Stavrianakis

$\mathrm{T}$

he United Kingdom is one of the more significant actors in the international arms trade. Between 2001 and 2005 it was the world's fifth largest supplier of major conventional weapons, behind Russia, the United States, France, and Germany, and the world's fifth largest recipient of arms, behind China, India, Greece, and the United Arab Emirates. ${ }^{1}$ The U.K. government supports arms exports because of the economic, strategic, and political benefits they ostensibly bring. It also claims to operate a very strict control regime based on the 2002 Export Control Act and a set of guidelines known as the Consolidated Criteria. Indeed, the government describes itself as being "at the forefront of promoting internationally the need to ensure defence exports are responsible." 2 As the examples later in this article suggest, despite this claim of strict control, it appears that the government continues to licence military equipment to states with a record of engaging in human rights violations, internal conflict, and regional instability. More generally, the scale of U.K. arms exports and the character of its traditional major recipients - NATO allies and Middle Eastern states, in particular Saudi Arabia, as well as states such as India and Indonesia - are such that the U.K. arms trade plays a significant role in maintaining the coercive backbone to the global capitalist system and the disproportionate military capabilities that exist across the globe. This article focuses on the arms export licensing process and asks how it is that, despite the existence of an ostensibly rigorous control process, controversial arms exports continue.

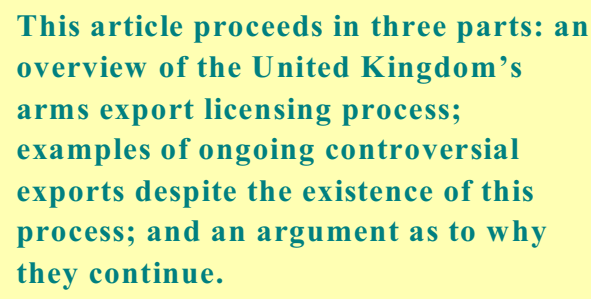

The article proceeds in three parts: an overview of the arms export licensing process; examples of ongoing controversial exports that continue despite the existence of this process; and an argument as to why these exports continue. I argue that such exports continue because of the vague wording of the guidelines; the framing of arms export policy; the limited use (from a control perspective) of a case-by-case approach; the weak role of pro-control departments within government; pre-licensing mechanisms that facilitate exports and a lack of prior parliamentary scrutiny, which means the government's policy can only be examined retrospectively; and the wider context of the relationship between arms companies and the U.K. state. ${ }^{3}$ The overarching argument is that the government's export control guidelines do not restrict the arms trade in any meaningful way but, rather, serve predominantly a legitimating function.

\section{Overview of the arms export licensing process}

The Consolidated EU and National Arms Export Licensing Criteria (hereafter, Consolidated Criteria) form the main regulatory mechanism for U.K. arms exports, setting out the government's commitment to be guided in its arms export activity by concerns regarding the state's international commitments, human rights, the internal situation in the recipient country, regional stability, U.K. national security, the recipient state's attitude to terrorism and international law, the risk of diversion, and sustainable development. ${ }^{4}$ The licensing process is administered and controlled by the Export Control Organization (ECO), which sits within the Department for Business, Enterprise and Regulatory Reform (BERR, formerly the Department of Trade and Industry, DTI). Companies submit an export licence application to ECO, which circulates the application within BERR and to the Ministry of Defense (MoD), Foreign and Commonwealth Office (FCO) and, where development concerns are an issue, Department for International Development (DfID). Each department gives a recommendation as to whether or not a licence should be granted, having assessed the application against some or all of the Consolidated Criteria. If departments or sub-departments cannot agree on a course of action, the licence application is referred to ministers for a decision. While "Number Ten," the Prime Minister's office, has no formal role in the licensing process, it will get involved where there is ministerial dispute over a decision and, more generally, plays a significant role in promoting arms exports as part of wider foreign relations.

The government is proud of its role as a leading arms exporter and states that "decisions to refuse licences are not taken lightly. Only in those cases where refusal is clearly justified is a final decision taken to refuse." This pro-export stance to the licensing process must be understood against the backdrop of extensive political and financial support for arms exports and arms-producing companies. This support comes in the form of contributions toward research and development costs, insurance cover against the risk of recipient default via the Export Credit Guarantees Department (ECGD, the government department that helps U.K. exporters win business by providing guarantees and insurance), the use of defense attachés, ministers, and the royal family in promoting arms sales abroad, the use of the intelligence services to promote arms exports, and, between 1966 and 2007, the role of the Defense Sales Organization (DSO), later renamed Defense Export Services Organization (DESO), a department of the $\mathrm{MoD}$ dedicated to promoting arms exports. ${ }^{6}$ This support is justified by reference to the ostensible economic, strategic, and political benefits arms exports bring. However, a recent study has challenged every justification put forward by the government, arguing that they remain, at best, unproven. ${ }^{7}$ More specifically, 
a 2001 study of the economic costs and benefits of U.K. arms exports, co-written by two MoD economic advisers, concluded that "the economic costs of reducing defence exports are relatively small and largely one-off" and that "the balance of argument about defence exports should depend mainly on non-economic considerations."

Ongoing controversial exports

The government claims that arms exports play a role in "deterring aggression and promoting stability by strengthening collective defence relationships." Notably, a large proportion of U.K. exports go to NATO allies, in particular the United States, and to Middle Eastern states. These transfers are significant in maintaining the stability of the capitalist system as they provide coercive resources to individual states and their military alliances. The U.K.'s arms relationship with Saudi Arabia is central to this: the Al Yamamah deals with Saudi Arabia in the late 1980s are the most lucrative military export deal in British history and made the U.K. the largest arms supplier to Saudi Arabia. More recently, in December 2005, the U.K. government signed a deal with the Saudi government to supply Eurofighter Typhoons. As Mike Turner, BAE Systems Chief Executive, put it: "The objective is to get the Typhoon into Saudi Arabia. We’ve had $£ 43$ bn from Al Yamamah over the last 20 years and there could be another $£ 40$ bn." 10 The U.K.'s arms relationship with Saudi Arabia is marked by extensive financial, political, and intelligence support as well as persistent secrecy and allegations of corruption in the form of bribery and slush funds. In late 2006 the Serious Fraud Office inquiry into these allegations was dropped, allegedly under pressure from then-Prime Minster Tony Blair and the Saudi government. ${ }^{1}$

Aside from core customers such as Saudi Arabia, the claim that the government acts to deter aggression and promote stability is problematic in relation to India and Pakistan. Tony Blair played a leading role in lobbying Indian Prime Minister Atal Behari Vajpayee in October 2002 to buy Hawk jets despite increased tension between India and Pakistan and widespread concern that it could escalate into a nuclear confrontation. In September 2003, B AE Systems secured a $£ 1$ bn deal to supply the Hawks. ${ }^{12}$ While the Hawk is most often described as a training jet, it can also be used as a ground attack aircraft and to train pilots to fly fast jets such as Jaguars, which can be adapted to carry nuclear weapons (and were previously sold to the Indian military by BAE Systems). ${ }^{13}$

Two pertinent examples relating to human rights are Israel and Indonesia. The U.K. government claims that it will not issue an export licence if there is a clear risk that the equipment might be used for internal repression. Yet it has a history of licensing components for combat aircraft, small arms, and ammunition to Israel, whose military has a record of human rights violations in the Occupied Territories. Applying the government's own guidelines on arms exports in 2002 should have resulted in a full embargo on military and security exports to Israel, according to Saferworld, an NGO working for tighter national and international arms control. ${ }^{14}$ In
July 2002, new guidelines were introduced in relation to transfers of equipment to a third country for incorporation and re-export. The guidelines were announced at the same time as licences were granted for the export of head-up displays to the United States for incorporation into F-16 fighter planes destined for Israel. ${ }^{15}$ The licensing of such equipment directly to Israel would have contravened the government's publicly stated arms export control guidelines as the Israeli air force has used F-16s in attacks on the Occupied Territories, but the new guidelines meant the equipment could be exported to the U.S. and, from there, incorporated into equipment for export to Israel. It is widely believed that the new guidelines were introduced in order to facilitate transfers such as this one. ${ }^{16}$ Also in 2002 however, 34 percent of all Standard Individual Export Licences (SIEL) applications were refused by government. (SIELs allow shipments of specified items to a specified consignee up to a quantity specified by the licence.) This signaled a rise in refusals: 10 percent of SIEL applications were refused in 2001 and 2 percent in 2000. The Quadripartite Select Committee takes this as evidence that "the licensing policy to Israel may have been tightened up," but without an explanation as to the change, if any, in policy, this remains "neither transparent nor accountable." 17 There is thus considerable ambiguity in the government's policy toward Israel, with developments in arms export policy simultaneously seeming to signal both approval and condemnation of its behavior toward Palestinians.

The government also regularly licences military and dual-use equipment to Indonesia, despite the state security forces' record of repression and human rights violations, particularly in resource-rich regions such as Aceh, East Timor, and West Papua. During the period of martial law in Aceh in 2003-04, for example, the government licensed components for aircraft machine guns, components for combat aircraft, components for tanks, technology for the use of combat aircraft, military helmets, gun silencers, and body armor. This was despite an increase in extra-judicial killings, disappearances, excessive use of force, torture, arbitrary arrest and detention, and sexual violence in this period as well as a clampdown on freedom of movement and communication that made accurate figures even harder to generate. In cases such as Israel and Indonesia, and more generally in relation to its export policy, the U.K. government claims that it abides by its guidelines. However, the lack of transparency around arms export licensing makes it difficult for independent observers to take this claim at face value. The government claims its licensing system is among the most transparent in the world, ${ }^{18}$ yet it remains impossible to ascertain what equipment was exported, to whom, and when, or what equipment was refused, to whom and when. The information that is publicly available suggests that arms exports are being licensed to states engaged in internal repression and regional instability.

Pieces of the puzzle

The analysis put forward thus far generates a puzzle: how is it that, despite the U.K. 
government's claim to a rigorous licensing process, exports of military equipment to states such as Saudi Arabia, India, Israel, and Indonesia continue? The government claims that all exports have been assessed against the Consolidated Criteria; it thus does not admit that contraventions of the Criteria occur. So one possible answer is that NGOs, campaign groups, journalists, and academics are making a fuss about nothing. Yet the U.K. is one of the world's largest arms exporters, U.K.-supplied military equipment is being used in repression and conflict around the world, and wider policies of military support give sanction to such behavior. This section discusses six key pieces of the arms export licensing puzzle: the wording of the arms export guidelines; the framing of arms export policy; the inadequacy of a case-by-case approach to licensing; the weak role of pro-control actors within government; pre-licensing mechanisms that facilitate exports; and the relationship between arms capital and the state.

Wording of the arms export guidelines

The Consolidated Criteria set out the guidelines against which licence applications are assessed. For example, a licence will be refused if there is a "clear risk" that equipment "might" be used in internal repression. While this wording is slightly more restrictive than past guidelines, the previous Conservative government also claimed that it scrutinized arms export licence applications on a case-by-case basis and would not licence exports if it thought they were likely to be used in internal repression. However, as early as 1998 the Trade and Industry Committee stated that the Labour Party's policy is "a rather less radical break with past policy than is sometimes represented to be the case," 19 and the same patterns of behavior and justification are being repeated. There is thus reason to believe that Alan Clark's statement during the Scott Inquiry still applies, namely that the guidelines are "so imprecise and so obviously drafted with the objective of flexibility in either direction - elasticity, shall I say - as to make them fair game." ${ }^{20}$

Any set of guidelines requires interpretation and quantification in order to be operationalized and, in research interviews, civil servants and NGO workers referred to the difficulties involved in this. However, time and again, the interpretations arrived at are conservative to the point of changing any reasonable meaning of words such as "risk," despite the best intentions of pro-control actors. The wording of the guidelines is deliberately vague so as to allow a pro-export policy to continue while permitting government to appear committed to a tight regulation of the trade.

\section{Permission by omission}

In addition to the wording of the guidelines, there is also the question of what they do not say. That is, U.K. arms export policy is configured in such a way as to keep exports to some countries outside the bounds of scrutiny. For example, the impact of arms transfers on sustainable development is assessed by DfID, which considers the economic capacity of the proposed recipient, levels of military expenditure, technical capacity and potential diversion of resources, and the legitimate security and defense needs of the recipient state when examining arms export licence applications to the world's poorest states (defined as states eligible for concessional loans from the World Bank's International Development

Association). ${ }^{21}$ In this process, exports to states such as Saudi Arabia and the United States, for example, are excluded by definitional fiat, despite their enormous levels of military expenditure and the debate that could be had as to whether such levels of spending constitute a legitimate need. U.K. policy is framed in such a way as to exclude some recipients from concern while focusing attention on others (in this case, the world's poorest states, who anyway do not account for a large proportion of the world's arms transfers).

Inadequacy of the government's case-by-case approach

Leading on from the framing of the government's arms export policy is the issue of its case-by-case approach to licensing. The government claims to assess each licence application on a case-by-case basis against the Consolidated Criteria with respect to the conditions in the recipient country. In the words of the Quadripartite Committee in relation to arms exports to Israel, which are applicable to wider policy, it remains unclear how the government assesses whether there is a "clear risk" that proposed exports might be used in internal repression and thus contravene Criterion Two. ${ }^{22}$ The inevitable time lag between the licensing of an export and the actual delivery of equipment is problematic because of the possibility of a change in circumstances in the recipient state. In part, the problem is one of implementation: risk assessment that took into account past use of military equipment (whether supplied by the U.K., another foreign government, or domestically produced) and possible future conflict would be a significant improvement on the current process. However, the government already claims that it carries out such risk assessment. Is the problem thus one of incompetence? Given the internal system of auditing (discussed below) and the lack of any admission that the government ever contravenes its guidelines, this is unlikely. Rather, the issue is the orientation of the wider policy toward arms exports: as long as government policy remains pro-export and the onus is to export wherever possible, 
the bureaucratic licensing process will remain insufficient for adequate control of exports. The case-by-case approach is a technical tool whose orientation and use depends on the values driving the policy behind it. As the licensing system is currently configured, even if exports are restricted to a particular state at times of tension, it will already be in possession of equipment previously transferred, and will be eligible for more transfers once flashpoints die down.

Weak role of pro-control actors within government

Within government, the main departments concerned to restrict the flow of weapons are DfID and the Human Rights Democracy and Good Governance Group (HRDGG, formerly Human Rights Policy Department, HRPD) within the FCO. DfID plays a lead role on small arms clean-up programs abroad, but in instances such as the Tanzania case, it is sidelined. In 2001 the DTI issued a licence to BAE Systems for the export of a $£ 28 \mathrm{~m}$ air traffic control system to Tanzania despite the public opposition of Clare Short, who was Secretary of State for International Development at the time, and other DfID officials. DfID's influence is thus at the margins of U.K. arms export policy.

As of 22 March 2007, there were three officers within HRDGG working on human rights concerns in the licensing process, two of whom dedicate approximately 40 percent of their time to this, and one of whom dedicates 15 percent. In 2006, HRDGG was consulted in relation to 631 licences. ${ }^{23}$ Given that 7,474 SIELs and 397 Open Individual Export Licences (OIELs, which cover multiple shipments of specified items to specified destinations or consignees) were issued in 2006, and 123 SIEL's and 9 OIEL's were refused, it seems that the proportion of licences HRDGG officials are consulted on is low, raising the question of who decides which licences HRDGG officials get to see and what capacity they have for scrutinizing licence applications. ${ }^{24}$ It also appears that, even when they are consulted, the opinion of HRDGG officials carries little weight within the licensing process. While these officials understand themselves as the "guardians" of the human rights criterion in the arms export guidelines, only a small number of refusals called for by them are upheld by ministers. In interviews, officials emphasized that their opinions are put forward during the process, but they have only an advisory role and call for more refusals than are upheld. ${ }^{25}$ The result is that in the majority of cases that HRDGG deal with (which is only a small proportion of total licence applications), its advice is not taken up as the FCO position.

More generally, there is an internal system of checks and balances and an auditing process within the FCO that the civil service claims ensures the process is carried out correctly and that departments are accountable, preventing a "loose canon" signing off licences. ${ }^{26}$ During periods of tension, such as the Aceh crisis in 2003, every licence for export to sensitive states requires ministerial approval. ${ }^{27}$ This means that controversial exports have not slipped through the net or been authorized by a rogue official. They are not an aberration in policy, they are the expression of it.

\section{Form 680 and lack of prior parliamentary scrutiny}

The Form 680 process and the lack of prior parliamentary scrutiny serve to facilitate arms exports. The Form 680 process (administered by the Directorate of Export Services Policy, DESP, which sits within DESO as part of the MoD) occurs before the formal licensing process and functions to give MoD clearance to companies for the sale, demonstration, promotion, or export of certain equipment, goods, or information that is classified. ${ }^{28}$ It gives companies "an indication of what markets may provide viable export opportunities for their products" and "speeds up the assessment of any eventual Export Licence Application." ${ }^{29}$ While F680 approval does not remove the necessity of complying with licensing requirements, it does give industry a good idea of what will be licensed and adds momentum to contracts that makes it harder for them to be refused at the licensing stage. As an industry lobby group argues, it plays a role in "enhancing the potential customer's comfort factor feeling that a licence would be issued by HMG." ${ }^{30}$ Thus, in addition to the weaknesses of the licensing process described above, there is a prior process that operates independently and serves to fast-track sales.

In addition to this pre-licensing approval, the parliamentary Quadripartite Committee (made up of representatives from the Defense, International Development, Foreign Affairs, and Trade and Industry Committees) has retrospective rather than prior scrutiny of the government's arms export record and policy. This means it can only comment on arms export licences after they are granted. In addition, when the Committee criticizes the government, such as on the issue of arms exports to Indonesia, the government simply said that it "does not accept" the Committee's conclusion. ${ }^{31}$ Even on the rare occasion that details of a controversial sale emerge prior to the granting of licences, such as the $£ 28 \mathrm{~m}$ air traffic control system to Tanzania in 2001 , the Committee was unable to prevent licences being granted. Parliament is thus in a weak position to be able to influence government policy

Relationship between arms capital and the state

The final piece of the puzzle is the relationship between arms capital and the U.K. state. Arms capital has been integrated into state structures and this relationship sets the overall orientation to arms exports. The parameters of defense industrial and arms export policy are configured to benefit major arms-producing companies, in particular BAE Systems, and means that control measures such as the Consolidated Criteria are vague and do not threaten the interests of industry. Similarly, the proposed legally binding international Arms Trade Treaty, which a coalition of NGOs is pushing for, has been promoted by the U.K. government and U.K.-based industry, which claims that the proposed treaty will not bring new obligations for it. ${ }^{32}$ 
The integration of arms capitalists into the structures of the U.K. state is the most significant indicator of the close, indeed overlapping, relationship between the state and arms capital. This integration occurs in two main ways, first, via a "revolving door" between the state and military industry, and, second, through high levels of arms company representation on military advisory bodies. ${ }^{33}$ The revolving door refers to the traffic of personnel between arms companies and the state, in particular the MoD, and specifically DESO, and vice versa. The most obvious expression of this is that the head of DESO is traditionally drawn from the arms industry and continues to draw pay from the industry during his stint at DESO. The current head, Alan Garwood, in post since 2002, is on secondment from MBDA, which is part-owned by BAE Systems. In addition to the revolving door, arms companies have a significant presence on military advisory bodies such as the National Defense Industries Council (NDIC), Defense Export and Market Access Forum (DEMAF), National Defense and Aerospace Systems Panel (NDASP), and Aerospace Innovation and Growth Team (AeIGT). Through these bodies, industry works in partnership with government to set policy priorities and means that industry has access to elite policymakers, officials, and politicians at the expense of non-corporate actors.

More generally, arms exports are legitimated by claims of national defense. The argument that arms exports are politically, economically, and strategically beneficial carries weight above and beyond its factual content because of the underlying ideological function of the term "defense," and claims regarding state sovereignty serve as a powerful justification for the very idea of an international trade in weaponry. Military activity and the arms trade have an almost sacred quality even among those elements of the state that are not embedded with arms capital. This is not to argue that that the state and capital's interests are identical, or that only policies beneficial to the military and arms industry come into being. Rather, it is to argue that there is a structural bent toward pro-military and pro-industry policies. Given that representatives of arms capital sit, literally, side by side with state officials and often perform state functions themselves, the integration of arms capitalists into the state generates an attitude toward policy, if not the actual specific details of policy, that are functional for arms capital in a way that would not otherwise be. Nevertheless, there is not a complete fusion of interests: there are vigorous and public disputes between fractions of the state and capital, often over domestic procurement issues, and large companies claim to be discriminated against by excessively stringent U.K. export guidelines.

\section{Conclusion}

The U.K. government claims to exercise a responsible arms export policy carried out through a strict licensing system. This claim is worth examining in light of ongoing exports to states involved in repression and regions experiencing conflict, and the sheer volume of U.K. exports. I argue that the guidelines against which arms export licence applications are assessed are vague and further weakened by a policy that excludes some states from scrutiny by definitional fiat and a case-by-case approach that isolates exports from wider policies of military support; that the departments most likely to restrict arms exports are institutionally weak; that procedures such as the Form 680 process function to give industry advance clearance for their products; and that Parliament is in a weak position that leaves it unable effectively to control the government or even call it to account. All of these factors must be understood in the wider context of the relationship between arms capital and the state. The integration of arms capital into state structures means that, rather than acting independently of commercial interests to regulate companies' behavior, the state has to a significant extent been captured by the arms industry and acts to a considerable extent in its interests. In light of this, despite the existence of a complex bureaucratic process and despite the best intentions and efforts of officials working in pro-control departments, high levels of arms exports continue, including those to states engaged in internal repression or regional instability. The licensing process is thus better understood as a ritualized activity that functions to create the appearance of control and image of benevolence and restraint.

Notes

Anna Stavrianakis is an ESRC Postdoctoral Fellow, Department of International Relations, University of Sussex. She may be reached at A.Stavrianakis@sussex.ac.uk. The research on which this article is based was conducted under an ESRC Postgraduate Studentship. Thanks to Neil Cooper, Rob Dover, Nick Gilby, Mike Lewis, and the editors for comments.

1. Hagelin, et al. (2006a, p. 450); Hagelin, et al. (2006b, p. 477).

2. Defence Export Services Organisation (n/d).

3. For the purposes of this article, arms companies are those that produce weapon systems or components in one or more sectors (e.g., artillery, missiles, electronics). Companies specializing in military-related communications, information technology, and services are also included under the broad label of "arms companies" because of the growing importance of such products and services to military efforts, and the growing salience of spin-in from civilian to military spheres (Sköns, et al. 2004, p. 397). The largest U.K.-based arms companies are BAE Systems (with 93 percent of revenue from defense in 2006), Rolls Royce (29 percent), Qinetiq (76.3 percent), GKN (20.2 percent), VT Group (70 percent), Cobham (61.4 percent), and, up to 2006 , Smiths (25 percent). See Defense News (2007). In January 2007 Smiths Group sold its aerospace unit to the U.S.-based company General Electric. As with the wider arms industry, these companies are internationalizing through cross-national mergers and 
acquisitions, multinational consortia, joint ventures, codevelopment and coproduction of products, licensed production (in which one company allows another to manufacture its products under licence), and offsets (in which sales involve some domestic sourcing of components, or inward investment to the buying country). These processes of internationalization are such that the biggest U.K.-based arms company, BAE Systems, is a significant actor in the U.S. defense industrial base, and companies such as French-owned Thales are labeled by the U.K. government as part of the U.K. defense industrial base. See O'Connell (2005). Neither arms-producing companies nor the defense industrial base are purely national, yet the government articulates arms exports as in the national interest.

4. MoD, et al. (2000).

5. MoD, et al. (2004a, p.12).

6. In July 2007 the Prime Minister, Gordon Brown, announced plans to close DESO and transfer support for arms exports or, in his words, "trade promotion for defence exports" to U.K. Trade and Investment. While this means that industry loses its privileged foothold in government, government-to-government deals remain under MoD control, and it remains unclear to what extent this signals a change in government policy toward arms exports.

7. Mayhew (2005).

8. Chalmers, et al. (2001, p. 3). More generally, on the economics of U.K. involvement in the arms trade, see Martin (2001); Dunne and Smith (1992). Dunne and Perlo-Freeman (2003) argue that there are no economic arguments against a more responsible arms export policy, in that banning arms sales to highly repressive regimes and countries in conflict would have no detectable impact on the U.K. economy.

\section{Defense Export Services Organization (n/d).}

10. Quoted in Leigh and MacAskill (2005)

11. Hope (2006); BBC (2006). For a history of corruption in the U.K. arms trade with Saudi Arabia, see Nicholas Gilby's contribution to this issue.

\section{Tran (2003).}

13. Norton-Taylor (2002).
14. Saferworld (2004, pp. 151-157).

\section{Davies (2002).}

16. White and Norton-Taylor (2002); Ahmed (2002).

17. Quadripartite Committee (2007, p. 135).

18. Foreign Office minister Baroness Symons, quoted in BBC (2004); Howells (2007).

19. Cited in Cooper (2000, p. 151).

20. Quoted in Norton-Taylor (1995, p. 43). Sir Richard Scott's "Report of the Inquiry into the Export of Defence Equipment and Dual-Use Goods to Iraq and Related Prosecutions" was published in 1996. It was the result of the inquiry started in 1992 in relation to the "arms-to-Iraq" scandal.

\section{DfID (2007).}

22. Quadripartite Committee (2007, p. 135).

23. McCartney (2007).

24. Data collected from Strategic Export Controls Quarterly Reports, January-March 2006, April-June 2006, July-September 2006, and October-December 2006.

25. Interview with FCO officials, 16 June 2004. One official estimated that 80 percent of licence applications that crossed their desk were submitted to ministers for a decision; another official disagreed that it was this high a proportion but the former was adamant that it was more than half.

26. Interview with a government official, 22 March 2005.

27. Interview with a government official, 7 March 2005.

28. DTI (2006).

29. MoD (2006).

30. Export Group for Aerospace and Defense (n/d). 
31. MoD, et al. (2004b).

32. Defense Manufacturers Association (2006).

33. For details, see Campaign Against Arms Trade (2005).

\section{References}

Ahmed, K. 2002. "Cabinet in Arms to Israel Row." The Observer. 7 July 2002.

BBC. 2004. "Criticisms after Arms Exports Rise." BBC News. 7 June 2004. http://news.bbc.co.uk/1/hi/uk_politics/3784965.stm [accessed 29 August 2007].

BBC. 2006. "Saudi Defence Deal Probe Ditched." 15 December 2006. http://news.bbc.co.uk/1/hi/business/6180945.stm [accessed 16 December 2006].

Brown, G. 2007. "Machinery of Government: Defence Trade Promotion." Hansard. 26 July 2007.

Campaign Against Arms Trade. 2005. "Who Calls the Shots? How Government-Corporate Collusion Drives Arms Exports." London: CAAT.

Chalmers, M., N. Davies, K. Hartley, and C.Wilkinson. 2001. "The Economic Costs and Benefits of UK Defence Exports." York: University of York Centre for Defence Economics.

Cooper, Neil. 2000. "The Pariah Agenda and New Labour's Ethical Arms Sales Policy," pp. 147-167 in R. Little and M. Wickham-Jones, eds. New Labour's Foreign Policy: A New Moral Crusade? Manchester: Manchester University Press.

Davies, M. 2002. "Straw Defends Arms Sales Change." BBC News Online. 9 July 2002. http://news.bbc.co.uk/1/hi/uk_politics/2110081.stm [accessed 4 December 2005].

Defence Export Services Organisation. [n/d] "Why Does the Government Support Defence Exporters?" http://www.deso.mod.uk/policy.htm [accessed 28 December 2006].

Defence Manufacturers' Association. 2006. “Arms Trade Treaty,” DMA News Issue 35, January 2006, p. 4, http://www.the-dma.org.uk/Intro/Newsletters/78.PDF.

Defense News. 2007. "Defense News Top 100.” http://defensenews.com/index.php? $\mathrm{S}=07$ top 100 [accessed 3 September 2007].

DfID. 2007. "Memorandum from the Department for International Development (DFID)," in Quadripartite Committee. "Strategic Export Controls: 2007 Review." London: The Stationery Office.

DTI. 2006. "Strategic Export Control - Licensing and Rating - Guidance." 21 September 2006. http://www.dti.gov.uk/europeandtrade/strategic-export-control/ licensing-rating/guidance/page8721.html [accessed 7 December 2006].

Dunne, P. and S. Perlo Freeman. 2003. "The Impact of a Responsible Arms Control Policy on the UK Economy." Report prepared for Oxfam. Available at
http://carecon.org.uk/Users/paul/Oxfamreport7.pdf [accessed 1 October 2007]. Dunne, P. and R. Smith. 1992. "Thatcherism and the UK Defence Industry," pp 91-111 in J. Michie, ed. The Economic Legacy 1979-1992. London: Academic Press.

Export Group for Aerospace and Defence. [n/d] "680 Advice." http://www.egad.org.uk/sw3163.asp [accessed 7 December 2006].

Hagelin, B., M. Bromley, and S.T. Wezeman. 2006a. "International Arms Transfers," pp. 449-477 in Stockholm International Peace Research Institute. SIPRI Yearbook 2005. Oxford: Oxford University Press.

Hagelin, B., M. Bromley, and S.T. Wezeman. 2006b. "The Volume of Transfers of Major Conventional Weapons: By Recipients and Suppliers, 2001-2005,” pp. 477-482 in Stockholm International Peace Research Institute. SIPRI Yearbook 2006. Oxford: Oxford University Press.

Hope, C. 2006. "SFO Drops BAE-Saudi Investigation.” The Telegraph. 15 December 2006. http://www.telegraph.co.uk/news/main.jhtml?xml=/news/ 2006/12/14/ ubae114.xml [accessed 16 December 2006].

Howells, K. 2007. Hansard. Written Ministerial Statements. 24 July 2007. Column $51 \mathrm{WS}$. http://www.publications.parliament.uk/pa/cm200607/cmhansrd/cm070724 /wmstext/70724m0001.htm\#07072482000157 [accessed 29 August 2007].

Leigh, D. and E. MacAskill. 2005. "Blair in Secret Saudi Mission." The Guardian. 27 September 2005.

Martin, S. 2001. "The Implications for the U.K. Exchequer of an Ethical Arms Export Policy," Applied Economics Vol. 33, pp. 195-199.

Mayhew, E. 2005. "A Dead Giveaway: A Critical Analysis of New Labour's Rationales for Supporting Military Exports." Contemporary Security Policy Vol. 26, No. 1 (April), pp. 62-83.

McCartney, I. 2007. Hansard. Written Answers. 22 March 2007. Column 1097-1098W.

[MoD] Ministry of Defence. 2006. "Guidance Notes on Completion of MoD Form 680." http://www.deso.mod.uk/pdfs/F680-Guidance.pdf [accessed 7 December 2006].

[MoD, FCO and DTI] Ministry of Defence, Foreign and Commonwealth Office, Department of Trade and Industry. 2000. "The Consolidated EU and National Arms Export Licensing Criteria." HC 199-203W, 26 October, pp. 413-416 in Strategic Export Controls, Annual Report 2001. London: FCO.

[MoD, FCO, DTI, and DfID] Ministry of Defence, Foreign and Commonwealth Office, Department of Trade and Industry, Department for International Development. 2004a. "Strategic Export Controls. Annual Report 2004.” London: The Stationery Office.

[MoD, FCO, DTI, and DfID] Ministry of Defence, Foreign and Commonwealth Office, Department of Trade and Industry, Department for International Development. 2004b. "Strategic Export Controls: Annual Report for 2002, 
Licensing Policy and Parliamentary Scrutiny. Response of the Secretaries of State for Defence, Foreign and Commonwealth Affairs, International Development and Trade and Industry." October 2004, http://www.fco.gov.uk/Files/kfile/

CM6357.pdf [accessed 19 May 2006].

Norton-Taylor, R. 1995. Truth is a Difficult Concept. London: Fourth Estate Limited. Norton-Taylor, R. 2002. "British Plane Sales to India Raise Fears of Nuclear Use." The Guardian. 23 April 2002.

O'Connell, D. 2005. "What Price Defence?" Management Today (October), p. 54. Phythian, M. 2000. The Politics of British Arms Sales since 1964. Manchester: Manchester University Press.

Quadripartite Committee. 2007. "Strategic Export Controls: 2007 Review.” London: The Stationery Office.

Saferworld. 2004. "An Independent Audit of the 2002 UK Government Annual Report on Strategic Export Controls." London: Saferworld.

Sköns, E., S. Bauer, and E. Surry. 2004. "Arms Production," pp. 379-418 in Stockholm International Peace Research Institute. SIPRI Yearbook 2004. Oxford: Oxford University Press.

Tran, M. 2003. "BAE Wins £1bn Hawk Contract.” The Guardian. 3 September 2003. White, M. and R. Norton-Taylor. 2002. "Straw Provokes Row over Arms for Israel." The Guardian. 9 July 2002. 